\title{
Article
}

\section{Researching the impact of the networked information environment on learning and teaching}

Zenios, Maria, Goodyear, Peter and Jones, Christopher

Available at https://clok.uclan.ac.uk/17459/

Zenios, Maria orcid iconORCID: 0000-0001-8625-4260, Goodyear, Peter and Jones, Christopher (2004) Researching the impact of the networked information environment on learning and teaching. Computers and Education, 43 (1-2). pp. 205-213. ISSN 0360-1315

It is advisable to refer to the publisher's version if you intend to cite from the work. http://dx.doi.org/10.1016/j.compedu.2003.12.014

For more information about UCLan's research in this area go to http://www.uclan.ac.uk/researchgroups/ and search for <name of research Group>.

For information about Research generally at UCLan please go to http://www.uclan.ac.uk/research/

All outputs in CLoK are protected by Intellectual Property Rights law, including Copyright law. Copyright, IPR and Moral Rights for the works on this site are retained by the individual authors and/or other copyright owners. Terms and conditions for use of this material are defined in the policies page.

\section{CLoK}

Central Lancashire online Knowledge www.clok.uclan.ac.uk

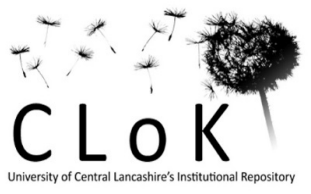




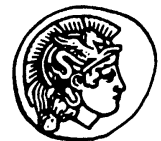

PERGAMON
Available online at www.sciencedirect.com

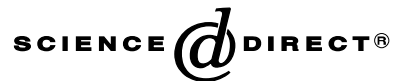

Computers \& Education xxx (2004) xxx-xxx
COMPUTERS \& EDUCATION

www.elsevier.com/locate/compedu

\title{
Researching the impact of the networked information environment on learning and teaching
}

\author{
M. Zenios ${ }^{\mathrm{a}, *}, \mathrm{P}$. Goodyear $^{\mathrm{b}}$, C. Jones ${ }^{\mathrm{a}}$ \\ ${ }^{a}$ Department of Educational Research, Centre for Studies in Advanced Learning Technology (CSALT), \\ Lancaster University, Lancaster LA1 4YL, UK \\ ${ }^{\mathrm{b}}$ CoCo, School of Development and Learning, University of Sydney, NSW 2006, Australia
}

\section{Abstract}

During the last decade, the focus of innovation and research in the field of computers and education has shifted from strand-alone to networked computers. The rapidly growing educational use of networked computers raises questions about which approaches to research can tell us most about improving educational impact. A key aim of this paper is to stimulate discussion about such research approaches by presenting a methodological case study of the use 'project logic' evaluation methods. The paper draws on our formative evaluation of what is currently the largest learning technology development programme in UK tertiary education. Originally called the Distributed National Electronic Resource (DNER) and more recently re-named the Information Environment (IE), this development is intended to create a managed environment for accessing quality-assured information resources on the Internet (DNER, 2002). These resources are intended for a variety of purposes in tertiary education, including research. However, our focus has been on the use, or likely use, of these resources for teaching and learning - something that was the intended focus of a substantial number of projects funded under the DNER/IE umbrella. The paper illustrates a method for helping project teams articulate their implicit theories about learning and change, which we argue are important in predicting and improving educational impact.

(C) 2004 Elsevier Ltd. All rights reserved.

24 Keywords: Evaluation methodologies; Evaluation of CAL systems; Pedagogical issues; Interactive learning environ25 ments; Adult learning

\footnotetext{
${ }^{*}$ Corresponding author. Fax: +44-1524-592914.

E-mail address: m.zenios@lancaster.ac.uk (M. Zenios).
} 


\section{Introduction}

The rapidly growing use of networked learning methods, especially in higher education, demands that we look closely at ways to research their educational potential and impact (Jones \& Steeples, 2002). There have been a number of advances in methods of developing the theory and practice of networked learning (e.g., Anderson, Day, Haywood, Haywood, Land, \& MacLeod, 2002; Levy, 2003; Salmon, 2002 and see the edited collection of Wasson, Ludvigsen, \& Hoppe (2003)). This paper builds upon their work and, in particular, shows how an evaluation research approach which helps uncover implicit theories of learning and change can predict gaps between what a project sets out to achieve and what it actually achieves.

This paper describes key parts of a research methodology for evaluating large-scale educational improvement initiatives. The methodology was developed as part of a formative evaluation of the pedagogical aspects of the DNER/IE programme undertaken by the Centre for Studies in Advanced Learning Technology (CSALT) at Lancaster University and the Centre for Research in Library and Information Management (CERLIM) at Manchester Metropolitan University. The DNER/IE programme has been funded by the UK's Joint Information Systems Committee (JISC) and aims to support improved access to, and use of, a wide range of quality-assured digital resources in UK higher and further education. The JISC vision of the IE strategy is that it will enrich students' learning experiences and improve the efficiency and quality of teaching and research (JISC, 2002). The effort is largely project-based. Most of the work is being done by several dozen project teams. Most of these teams include personnel drawn from several UK organisations (mostly universities).

It is the actual and potential impact, on learning and teaching, of the services, collections and other project outputs, offered within the networked IE, that the research approach described here aims to explore. The approach involved a set of 11 evaluation studies conducted at the level of individual IE projects. The outcomes from our evaluation work illuminate aspects of the methodology and some of the problems in the logic connecting projects' intentions and activities.

\section{Perspectives informing the research approach}

Our approach reflects three fundamental principles. First, our evaluation was tasked with exploring the actual and potential educational benefits of IE developments within UK higher education. This puts the focus firmly on learning and especially on how IE resources are being used, or are likely to be used, in the day-to-day study activity of higher education students. What is provided is less important than what students actually do, or are likely to do, with what is provided. Second, what students do is strongly influenced - though not determined - by their interpretation of the demands placed upon them by their teachers. In deciding how to allocate their increasingly scarce time, most students will prioritise use of those information resources which their teachers lead them to believe will be important in meeting the assessment demands placed upon them. (The general case is made, for example, in Ramsden \& Entwistle (1981) and reprised in Biggs (1999)). The case in regard to use of digital information resources is made in Goodyear (2000b). Finally, whether or not teachers choose to recommend a digital information resource will depend heavily on the extent to which the people developing or improving access to that resource have understood how a teacher can incorporate its use into their curriculum. 
In consequence, our approach involves surfacing the 'implicit theories of learning and change' embedded in the work of the IE project teams. These implicit theories are unarticulated or partially articulated sets of assumptions about how learning occurs, how learners can make use of digital learning resources and what needs to be done to make these resources accessible and useful in real learning situations (Goodyear \& Jones, 2003). The approach we use builds on the work of Nash, Plugge, and Eurelings (2000), Strömdahl and Langerth Zetterman (2002) and of McLaughlin and Jordan (1998). McLaughlin and Jordan developed the idea of using a graphical depiction of 'project logic' as an aid to the formative and summative evaluation of an intervention project. It is a version of the more widely known method of 'theory-based evaluation'. Nash et al. (2000) and Strömdahl and Langerth Zetterman (2002) suggested how such an approach might work in the specific context of ICT-based educational innovations. In brief, the 'project logic' approach involves helping the members of a project team construct a representation of the logical connections within their project - such that implicit and explicit connections can be brought into common view. The connections concerned are the linkages between the inputs to a project, its intermediate products, its final products (or 'outputs') and its intended and actual benefits ('outcomes'). The approach helps project teams to see and air differences that may exist within and around their projects, to improve consensus and to enhance the internal logic of the project. A central point of our approach has been to help create a shared understanding of what project teams thought would change in educational practice and how their actions would lead towards those changes. Since the approach includes opportunities for project teams to reflect on their activities, and on the likely impact of their work on learning and teaching, there are similarities with methods of action research that emphasise reflective practice (cf. Levy, 2003; Salmon, 2002).

\section{Methods used in the study}

In the first phase of data gathering we asked 62 team members from some 35 IE/DNER projects to write down:

- the intended benefits of their projects;

- the people who they expected would turn the project outputs (deliverables) into real educational benefits and the actions these people would take to achieve these benefits;

- the ways in which their project might work to involve such people in a timely and sustainable fashion.

The information collected from the project team members was analysed in two main ways. First, a simple quantitative content analysis was carried out, to summarise the responses to these three questions. (Only $25 \%$ of the respondents spontaneously wrote about enhancing learning. The rest talked about more, easier and better uses of information resources and services.) Second, we constructed logic tables showing the linkages between project activities, outputs, beneficiaries reached and outcomes. Activities include the action steps taken by the projects to produce outputs. Outputs are the IE products and/or services provided by the project to its intended beneficiaries (mostly higher education students). Outcomes are the changes or benefits for learners resulting from the project outputs. Outcomes can be short-term or longer-term: benefits will not always be immediate and some modest short-term changes can multiply into significant longerterm benefits (or, conversely, can fail to have any longer-term effects). The data collected from the 
107 project team members were categorised and tagged into the columns of the logic table, while the

108 accuracy of the information contained was triangulated with other sources, such as project plans,

109 reports and websites. This representation of the data is too extensive to reproduce here but the

110 interested reader can consult the evaluation report (Jones, Zenios, \& Goodyear, 2003).

111 As the next step in the study, 11 active projects were selected for further investigation based on

112 the following criteria: (a) the quality of the information we were able to obtain about them and (b)

113 an indication that some impact on learning and teaching had been achieved. We also tried to

114 include projects from each of the IE/DNER cluster groups, which were organised around themes

115 such as the use of digital audio resources, or still images or video. A logic diagram was created for

116 each one of the 11 projects. To express these concisely we used fewer terms than in the master

117 logic table. The new logic diagrams show the inputs, outputs and outcomes for specific groups of

118 beneficiaries. Fig. 1 gives a simple example.

119 The work involved in creating, critiquing and refining these logic diagrams 'brings to the 120 surface' the project teams' implicit theories of learning and change. Each diagram was developed,

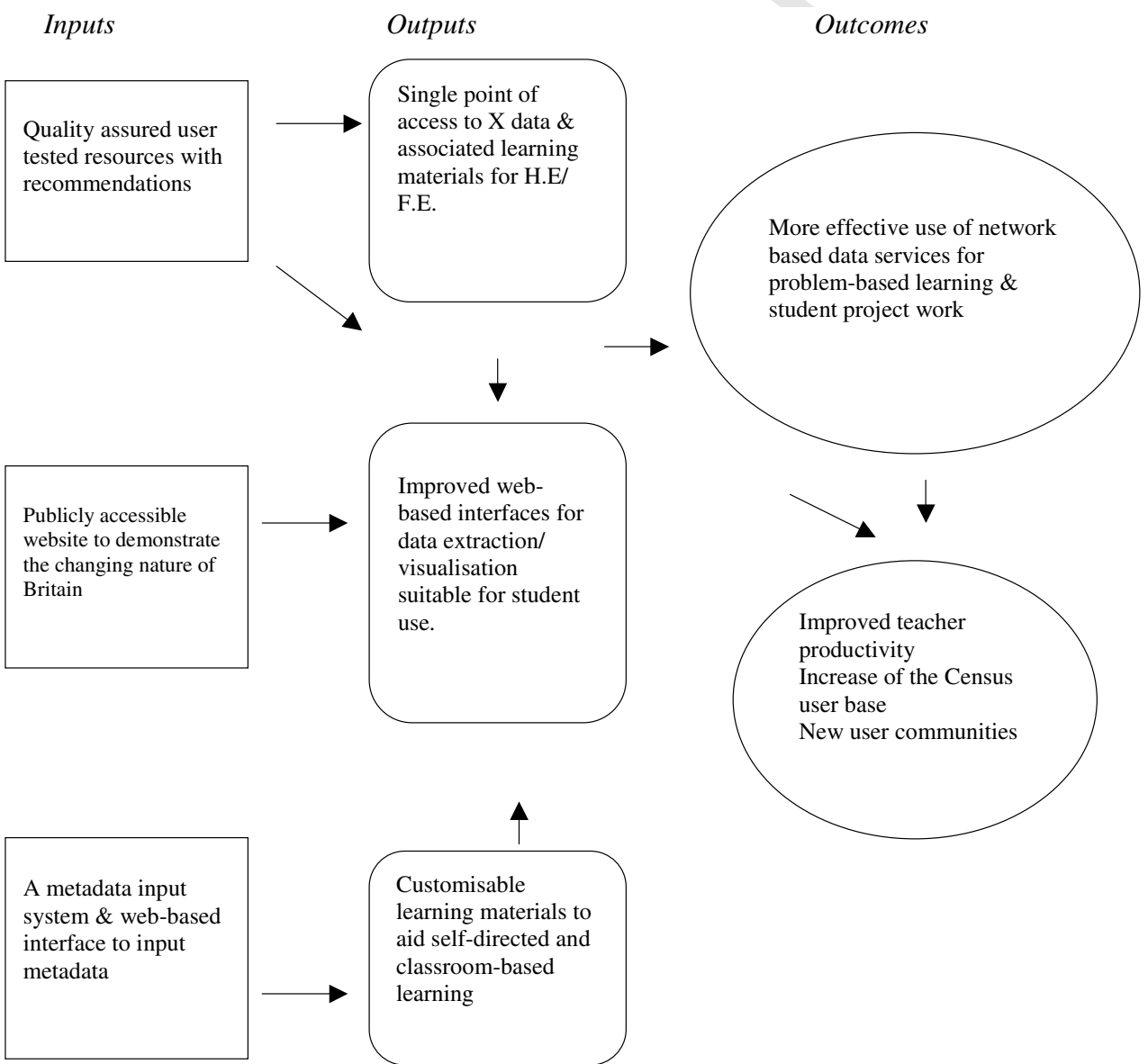

Fig. 1. Example project logic map. 
121 revised and elaborated through discussions with project team members. The diagrams were re-

122

123

124

125

126

127

128 visited and refined over time, bearing in mind particularly the need to answer the question of how the projects could help to promote learning and teaching. As we have seen, project teams had a strong tendency to restrict their talk to access and technical issues. Articulating the pedagogical and educational change issues needed our prompting, in most cases.

Issues emerging from this process of creating and improving the logic diagrams, for each of the 11 projects, are discussed in the following section. (Note. We have taken care not to identify individual projects and to concentrate on general themes and issues.)

\section{4. Emerging issues}

130 Most projects came to understand that they needed to work on improving the design and 131 promotion of their products (outputs) in order to secure their transformation into sustainable

132

133

134

135

136

137

138

139

140

141

142

143

144

145

146

147

148

149

150

151

152

153

154

155

156

157

158

159 educational benefits. (This was not a common understanding in the early days of the projects.) Most, but not all, projects showed a sense of responsibility for meeting the needs of their user communities. Over the lifetime of some of the projects, the focus changed due to new understandings of the needs of the end-users, as well as technological developments. In a few projects, the development of the final product was significantly affected by a diversity of views within the project team and agreement on common values and beliefs had to be worked out during the process. Consequent shifts of emphasis often led to creation of a product or resource different than that initially planned.

Other aspects of improved understanding within project teams concerned distinct pedagogical approaches and/or needs of learners and teachers within specific subject disciplines. Such understandings had a better potential to help teachers enrich the learning process through effective integration of the information resources. (It is important to note that project outputs were quite diverse and included reports, guidelines, discovery tools, software and websites, for example, as well as collections of digital resources and information services.)

Most of the projects conducted requirements analysis and formative evaluation, using either case studies or problem scenario studies, to inform the design and delivery of the materials or resources and to provide feedback on the educational effectiveness of the resources. In some cases, evaluation criteria and frameworks were developed, and guidelines emerged, from the user community. The information and new knowledge generated from the projects were usually offered through websites, e-lists and workshops targeted towards end-users.

In general terms, our understanding of the complex environment that is the IE has been aided by an articulation of the project teams' implicit theories and by attempts to specify and connect the inputs, outputs and outcomes involved in their work. The development of logic diagrams has enabled an investigation of the processes through which learning resources are brought into being by project teams and the ways in which they are made available to users. It has also helped project teams become more conscious of gaps and inconsistencies in the logic connecting their actions to their goals. The remainder of our analysis focuses on three main areas: (1) access to information resources, (2) learning activity and (3) pedagogical design. 


\subsection{Access to information resources}

161 An earlier study of the IE (Goodyear \& Jones, 2003) suggested that projects fall into two 162 categories: (i) those which only talk about making new or better resources available to students, or 163 about improving students access to such resources and (ii) those which went 'beyond access' by

164 describing ways in which learners may use these resources in their learning activity. Projects were 165 held to be looking 'beyond access' if any of the following featured in their self-descriptions: (a) 166 describing intended or envisaged learning activity, (b) providing learner and/or teacher support 167 materials to help with the integration of the resources in the curriculum or (c) working with 168 teachers in the development of the information resources. In the current study, we investigated the 169 extent to which the 11 selected projects went 'beyond access'.

170 As Table 1 indicates, three of the projects (7, 10 and 11) make no direct reference to learning. The 171 remaining eight projects make some, through rather limited, reference to learning activities. Seven 172 projects aim to provide either learner or teacher support materials and eight projects are expecting 173 to have some level of involvement of teachers in the development of their resources. However, even 174 the projects that go 'beyond access', through either providing related activities and resource ma175 terials for learners or involving teachers during the process of the development of their outputs, do 176 not seem to hold pedagogically informed beliefs about learning activities - in the sense that they do 177 not hold clear views about how learning activities will relate to the information resources.

178 There are good reasons to believe that simply making resources available to students will have 179 no impact on the quality of their learning and students will certainly need a reason to use such

Table 1

Projects' descriptions of ways in which learners may use their resources

\begin{tabular}{|c|c|c|c|}
\hline Project & Intended learning activity & $\begin{array}{l}\text { Learner/teacher support } \\
\text { materials }\end{array}$ & $\begin{array}{l}\text { Involvement of teachers in } \\
\text { resource development }\end{array}$ \\
\hline Case study 1 & $\begin{array}{l}\text { Re-use and sharing of } \\
\text { collections }\end{array}$ & Supportive material & $\begin{array}{l}\text { From beginning to end of } \\
\text { project }\end{array}$ \\
\hline Case study 2 & $\begin{array}{l}\text { Day-to-day work of pilot } \\
\text { departments }\end{array}$ & Guidelines & Teacher-authors \\
\hline Case study 3 & $\begin{array}{l}\text { Use of resources within } \\
\text { VLEs (Virtual Learning } \\
\text { Environments) and linked } \\
\text { to assessment }\end{array}$ & $\begin{array}{l}\text { Course-specific/teaching } \\
\text { tools }\end{array}$ & $\begin{array}{l}\text { Collaborated with team } \\
\text { from start }\end{array}$ \\
\hline Case study 4 & $\begin{array}{l}\text { Problem scenarios but not } \\
\text { tested with users }\end{array}$ & None mentioned & In evaluation \\
\hline Case study 5 & $\begin{array}{l}\text { Case studies: use and } \\
\text { testing of resources }\end{array}$ & Guide & In case studies \\
\hline Case study 6 & Workshops, exercises. & $\begin{array}{l}\text { Tutorials, exercises and } \\
\text { case studies }\end{array}$ & $\begin{array}{l}\text { Three learning and } \\
\text { teaching groups involved }\end{array}$ \\
\hline Case study 7 & $\begin{array}{l}\text { Experienced problems in } \\
\text { activity }\end{array}$ & Guidelines & Problematic \\
\hline Case study 8 & Workshops & Documentation & Dialogue and partnerships \\
\hline Case study 9 & $\begin{array}{l}\text { Interdisciplinary } \\
\text { workshops }\end{array}$ & Learning paths & $\begin{array}{l}\text { Evaluation feedback and } \\
\text { links }\end{array}$ \\
\hline Case studies 10 and 11 & None & None & No teacher involvement \\
\hline
\end{tabular}


180 resources and use them effectively. As we have suggested, factors that can be influential in de-

181

182

183

184

185

186

187

188

189

190

191

192

193

194

195

196

197

198

199

200

201

202

203

\section{4}

205

206

207

208

209

210

211

212

213

214

215

216

217

218

219

termining the successful use of resources in learning are (a) integration of resources with learning tasks set by the teacher, (b) assessment of student learning outcomes, especially when assessment counts towards the students' degree results and (c) assessment criteria distinguishing outcomes that are the consequences of poor, satisfactory and excellent use of resources. In this case there is an increased probability that students will use the resources in an effective way, or at least that they will weigh the consequences of not using the resources more seriously.

\subsection{Learning activity}

The success of a learning episode is strongly conditioned by the students' activity - especially their mental activity, but also their physical and social activity - their use of artefacts and their interactions with others (Biggs, 1999). Although learning activity cannot be controlled, there can be some ways to influence what the learner does by articulating educational objectives and constructing productive learning tasks appropriate to those objectives (Goodyear, 2000a). As learners become engaged in an activity it is important to offer them the option of customising and reconfiguring tools and resources in order to progress toward their goals. In researching the IE, we found that most of the projects examined have thought about possible integration of their products with learning activities. Although eight of the project teams have some views about the ways in which teachers in higher education can seek to connect information resources with the rest of their wider learning environment, insufficient attention is being paid to the relationship between learning activity and information resource. The project teams often rely implicitly on the mediation of third parties (especially teachers) to shape the nature of learning activities and their outcomes, even though these people are not directly involved in the design of the resources. Our approach of focussing on implicit theories of change highlighted the significance of involving these important intermediaries - especially teachers - in the design and testing of the information resources.

\subsection{Pedagogical design}

In exploring each project logic diagram, we looked for an explicit pedagogical rationale. Of all 11 projects, only three appear to have such a pedagogical rationale (see Table 2).

Among the remaining eight projects, in particular, there is an assumption that the use of networked technologies will lead to definite educational outcomes and possibly change practice in higher education simply by making resources available to students. Two projects in particular are committed to research on technical developments without seeking to link the gap between technology and pedagogy. The lack of an explicit pedagogical rationale may make it harder for the projects to convey the educational value of their work, which may in turn make it harder for others (especially teachers in higher education) to recognise, evaluate, take up and integrate the project outcomes into their teaching and learning practices. At the moment, there is no clear vision for increasing student access to the learning possibilities offered within the networked information environment, or for providing the conditions for authentic learning using project outputs. Additional actions are needed to make the jump from project outputs to real benefits for the user community. In designing further IE initiatives, it will be important to encourage better and earlier communication, within and between project teams, in order to achieve a clearer and 
Table 2

Assumptions about pedagogical purpose

\begin{tabular}{|c|c|}
\hline Project & Assumptions about pedagogical purpose \\
\hline Case study 1 & $\begin{array}{l}\text { There is a need to create a learning object database used by students, to the improvement of } \\
\text { their information skills }\end{array}$ \\
\hline Case study 2 & $\begin{array}{l}\text { Better language learning outcomes are achieved because of greater exposure to spoken } \\
\text { language and use of resources with fellow students enabled through the use of technology }\end{array}$ \\
\hline Case study 3 & $\begin{array}{l}\text { There exists a set of museum resources that are being digitised, enhanced through parallel } \\
\text { development of teaching tools and finally integrated within specific courses and thus leading } \\
\text { to increased use of museum resources in teaching }\end{array}$ \\
\hline Case study 4 & $\begin{array}{l}\text { Student performance is increased through providing seamless access to information resources } \\
\text { (e.g., library-mediated and broader resources from within VLEs) }\end{array}$ \\
\hline Case study 5 & $\begin{array}{l}\text { A knowledge base in using of video streaming resources, frameworks and tools needs to be } \\
\text { developed if we are to make appropriate pedagogical decisions }\end{array}$ \\
\hline Case study 6 & $\begin{array}{l}\text { Seamless access and improved web-based interfaces for data extraction/visualisation are } \\
\text { needed to increase the Census user base and enhance student project work }\end{array}$ \\
\hline Case study 7 & $\begin{array}{l}\text { The provision of a learning technology portal with resource submission, access and discovery } \\
\text { facilities has the potential to engage staff and students in learning technology }\end{array}$ \\
\hline Case study 8 & $\begin{array}{l}\text { There exists a set of data, which are expected to be used more frequently and effectively, thus } \\
\text { enhancing learning after the development of related web-based tutorial packs }\end{array}$ \\
\hline Case study 9 & $\begin{array}{l}\text { A package of online resources (graphics, images and text) is being made available to enhance } \\
\text { interdisciplinary student access to and use of specialised collections }\end{array}$ \\
\hline Case study 10 & $\begin{array}{l}\text { Optimised access to customised materials and resources assist in the advancement of } \\
\text { knowledge }\end{array}$ \\
\hline Case study 11 & $\begin{array}{l}\text { Visibility and accessibility of resources focusing on machine-to-machine interchange increase } \\
\text { user base }\end{array}$ \\
\hline
\end{tabular}

220 more robust linkage of project inputs and intended outcomes and to enable richer forms of in221 teraction between learners and materials in order to improve student learning.

\section{5. Summary and conclusions}

223 Data collected from 39 IE projects enabled the selection of a subset of projects as case studies 224 for investigating the processes used to achieve impact on learning and teaching. A logic diagram 225 was created for each one of the selected projects, showing the interconnection between the pro226 jects' activities, outputs and intended outcomes (educational benefits). Elaboration and refinement 227 of the logic diagrams, in communication with the team members, proved to be a useful resource 228 for their internal discussions. This discussion has helped project teams articulate their theories of 229 learning and change, and has enabled some of them to move 'beyond access' towards a better 230 planning of integration between resources and students' learning activity.

\section{Uncited reference}




\section{Acknowledgements}

234

235

236

237

238

239

This work was funded by JISC (Joint Information Systems Committee) of the UK higher education funding councils. The views expressed in this paper are solely those of the authors and they do not represent the views of JISC. We thank JISC for their support, our CERLIM colleagues for many interesting discussions and all the project teams for their participation in this study.

\section{References}

Anderson, C., Day, K., Haywood, D., Haywood, J., Land, R., \& MacLeod, H. (2002). Evaluating networked learning: Developing a multi-disciplinary, multi-method approach. In C. Steeples \& C. Jones (Eds.), Networked learning: Perspectives and issues. London: Springer.

Biggs, J. (1999). Teaching for quality learning at university: What the student does. Buckingham: Open University Press. Goodyear, P. (2000a). Environments for lifelong learning: Ergonomics, architecture and educational design. In J. M. Spector \& T. Anderson (Eds.), Integrated and holistic perspectives on learning, instruction and technology: Understanding complexity (pp. 1-18). Dordrecht: Kluwer Academic Publishers.

Goodyear, P. (2000b). Seeing learning as work: Implications for understanding and improving analysis and design. Journal of Courseware Engineering, 2, 3-11.

Goodyear, P. (2002). Psychological foundations for networked learning. In C. Steeples \& C. Jones (Eds.), Networked learning: Perspectives and issues. London: Springer.

Goodyear, P., \& Jones, C. (2003). Implicit theories of learning and change: Their role in the development of e-learning environments for higher education. In S. Naidu (Ed.), Learning and teaching with technology: Principles and practices. London: Kogan Page.

JISC (2002). Adding value to the UK's learning, teaching and research resources, 3rd joint programmed meeting, January 24-25, 2002, Manchester. Available: http://jisc.ac.uk/dner/development/IEstrategy.html.

Jones, C., \& Steeples, C. (2002). Perspectives and issues in networked learning. In C. Steeples \& C. Jones (Eds.), Networked learning: Perspectives and issues. London: Springer.

Jones, C., Zenios, M., Goodyear, P. (2003). Report on the formative evaluation of teaching and learning aspects of the IE/DNER. Lancaster: CSALT.

Levy, P. (2003). A methodological framework for practice-based research in networked learning. Instructional Science, $31(1 / 2), 87-109$.

McLaughlin, J., Jordan, G. (1998). Logic models: A tool for telling your programme's performance story, June 5, 2001. Available: http://www.pmn.net/education/Login.htm.

Nash, J., Plugge, L., Eurelings, A. (2000). Designing and evaluating CSCL projects, Paper presented at the European conference on computer supported collaborative learning 2000, Maastricht.

Ramsden, P., \& Entwistle, N. (1981). Effects of academic departments on students' approaches to studying. British Journal of Educational Psychology, 51, 368-383.

Salmon, G. (2002). Approaches to researching teaching and learning online. In C. Steeples \& C. Jones (Eds.), Networked learning: Perspectives and issues. London: Springer.

Strömdahl, H., \& Langerth Zetterman, M. (2002). Theory-anchored evaluation an attempt to increase ownership in evaluation in higher education. Stockholm, Sweden: KTH Learning Laboratory.

2 Wasson, B., Ludvigsen, S., \& Hoppe, U. (Eds.). (2003). Designing for change in networked learning environments. Dordrecht: Kluwer. 